\title{
IDH1 R132H Negative
}

National Cancer Institute

\section{Source}

National Cancer Institute. IDH1 R132H Negative. NCI Thesaurus. Code C136746.

A finding indicating that a mutation of the IDH1 gene encoding the amino acid substitution $\operatorname{Arg} 132 \mathrm{H}$ is $(\mathrm{R} 132 \mathrm{H})$ in the isocitrate dehydrogenase [NADP] cytoplasmic protein has not been detected in a sample. 